\title{
Temperature tolerance and daylength effects in isolates of Scytosiphon lomentaria (Phaeophyceae) of the North Atlantic and Pacific Ocean
}

\author{
Inka tom Dieck \\ Biologische Anstalt Helgoland (Zentrale); Notkestr. 31, D-2000 Hamburg 52, Federal \\ Republic of Germany
}

\begin{abstract}
Fifteen geographical isolates of Scytosiphon lomentaria were investigated for their daylength response with regard to upright thallus formation, and nineteen isolates for their upper temperature tolerance. Six new day-neutral and two new photoperiodic strains were found. It became evident that day-neutral strains represent a common reaction group in this species, besides the photoperiodic group. The temperature regulation of photoperiodic and day-neutral strains did not show striking differences and it is assumed that temperature regulation may trigger seasonality of occurrence in this species as well as photoperiod. The upper survival temperature after two weeks of heat stress is $28-29^{\circ} \mathrm{C}$ in all tested isolates. No temperature ecotypes were found.
\end{abstract}

\section{INTRODUCTION}

Scytosiphon lomentaria is a cosmopolitan brown alga developing a filamentous or crustose microthallus and a tubular, constricted macrothallus in the cylindrical form or a flattened, unconstricted macrothallus in the complanate form of the species. Several isolates from different localities of this species form upright thalli from the crust only after short-day induction (Lüning, 1980). However, there are also reports on day-neutral strains of $S$. lomentaria from Australia, Denmark, Greenland, and eastern Canada (Clayton, 1976a, 1976b, 1978; Kristiansen \& Pedersen, 1979; Pedersen, 1980; Correa et al., 1986). The first objective of the present investigation was to tackle the question of whether non-photoperiodic strains are only accidental findings, or are more common and represent another important reaction group of the species.

Temperature has so far been considered to be of minor regulatory importance for the life history of $S$. lomentaria, in contrast to photoperiodic regulation. However, Correa et al. (1986) showed the strong temperature-dependence of a day-neutral complanate isolate in eastern Canada. This isolate developed many upright thalli independent of daylength at $0-10^{\circ} \mathrm{C}$, very few at $15^{\circ} \mathrm{C}$, and none at $20^{\circ} \mathrm{C}$. The importance of temperature control with regard to geographical distribution of $S$. lomentaria has been discussed by van den Hoek (1982). He emphasized that few experimental data were available in regard to upper limits of temperature tolerance. Moreover, since Bolton (1983) discovered intraspecific ecoclinal variation in Ectocarpus siliculosus with respect to temperature tolerance, the investigation of several isolates of one species, especially those from the 
extremes of its geographical range, is advisable. The second objective of this investigation was to test about twenty isolates from different localities of $S$. lomentaria not only for their daylength response but also for their upper temperature tolerance.

\section{MATERIALS AND METHODS}

The unialgal isolates of Scytosiphon lomentaria investigated in this study are listed in Table 1; they had been in culture for several years. All experiments were started from zoids derived from upright thalli of the isolates.

Test on daylength and temperature responses in the formation of upright thalli

The zoids of each isolate were inoculated in sterile plastic Petri dishes $(50 \mathrm{~mm}$ diameter) filled with about $20 \mathrm{ml}$ heat-sterilized Provasoli's Enriched Seawater (PES) at $50 \%$ strength (Provasoli, 1968; iodide enrichment according to Tatewaki, 1966). Immediately after seeding, the zoids were subjected to 15 test conditions, using special light cabinets described by Lüning (1980). Three daylength regimes in each of five constant temperature rooms were used. Temperatures: $0^{\circ} \mathrm{C}, 5^{\circ} \mathrm{C}, 10^{\circ} \mathrm{C}, 15{ }^{\circ} \mathrm{C}$ (all $\pm 1{ }^{\circ} \mathrm{C}$ ) and $20^{\circ} \mathrm{C}\left( \pm 2{ }^{\circ} \mathrm{C}\right)$. Daylength regimes: $8: \overline{16}$ light/dark (SD), $16: \overline{8}$ light/dark (LD), 8: $\overline{7.5}: 1: \overline{7.5}$ light/dark/light/dark (LB; light-break regime). A photon fluence rate of $40 \mu \mathrm{mol} \mathrm{m} \mathrm{m}^{-2} \mathrm{~s}^{-1}$ was provided by fluorescent tubes (Osram L $65 \mathrm{~W} / 19$, daylight 5000 DeLuxe). The medium in the Petri dishes was changed weekly. After 4 weeks and then every two weeks the proportion of upright thalli for each test condition was quantitatively determined by counting 500 plants within each sample. The experiment was completed when after another observation period of 2 weeks no new information could be added. Usually, the duration of an experiment was 6-8 weeks, and each experiment was performed twice. The strains of Lanzarote (No. 2502) and Thessaloniki (No. 2524) were not tested under all conditions described, but only once at $10^{\circ} \mathrm{C}$ in SD, LD and LB conditions.

\section{Temperature tolerance test}

The upright thalli of each isolate were cultivated at $5^{\circ} \mathrm{C}$, under LD conditions. For the test on temperature tolerance, the zoids of each isolate were inoculated over sterile glass slides in sterile crystallizing dishes (90 mm diameter) filled with autoclaved Von Stosch's Enriched Seawater (VSES; modified after Guiry \& Cunningham, 1984). The zoids were allowed to settle for one day. Subsequently, the glass slides with the fixed germlings were put into small sterile glass tubes ( $25 \mathrm{~mm}$ diameter, $55 \mathrm{~mm}$ high), again filled with VSES at a temperature of $5-10^{\circ} \mathrm{C}$. The glass tubes were used to ensure that all the germlings were retained for post cultivation including those that might have become detached during the temperature test. The glass tubes with the enclosed germlings were then submitted to the experimental temperatures $\left(25^{\circ}, 26^{\circ}, 27^{\circ}, 28^{\circ}, 29^{\circ}, 30^{\circ} \mathrm{C}\right.$; all $\pm 0.1{ }^{\circ} \mathrm{C}$ ), without prior adaptation. For further details concerning the incubation system see Lüning \& Guiry (1987). The seawater medium used was VSES at $50 \%$ strength which was changed automatically once a day. The enrichment according to von Stosch, which does not contain Tris buffer as an additional carbon source for bacteria (van der Meer, 1981) was used in order to suppress bacterial growth at the relatively high temperatures 
Table 1. Survey of isolates of Scytosiphon lomentaria. References refer to former investigations of the corresponding strains

\begin{tabular}{|c|c|c|c|c|c|}
\hline $\begin{array}{l}\text { Culture } \\
\text { number }\end{array}$ & Locality & $\begin{array}{l}\text { Collection } \\
\text { site }\end{array}$ & $\begin{array}{l}\text { Year of } \\
\text { collection }\end{array}$ & Collector & Reference \\
\hline 2003 & $\begin{array}{l}\text { Helgoland } \\
\text { (West-Germany) }\end{array}$ & $\begin{array}{c}54.09^{\circ} \mathrm{N} \\
7.53^{\circ} \mathrm{E}\end{array}$ & 1974 & K. Lüning & Lüning (1980) \\
\hline 2008 & $\begin{array}{l}\text { Isle of Man } \\
\text { (Great Britain) }\end{array}$ & $\begin{array}{l}54-55^{\circ} \mathrm{N} \\
04-05^{\circ} \mathrm{W}\end{array}$ & 1974 & K. Lüning & \\
\hline 2009 & $\begin{array}{l}\text { Seattle } \\
\text { (Washington, USA) }\end{array}$ & $\begin{array}{r}47.35^{\circ} \mathrm{N} \\
122.20^{\circ} \mathrm{W}\end{array}$ & 1974 & K. Lüning & Lüning (1980) \\
\hline 2011 & $\begin{array}{l}\text { Rovinj } \\
\text { (Yugoslavia) }\end{array}$ & $\begin{array}{l}45.05^{\circ} \mathrm{N} \\
13.40^{\circ} \mathrm{E}\end{array}$ & 1975 & K. Lüning & Lüning (1980) \\
\hline 2013 & $\begin{array}{l}\text { Flinders } 1 \\
\text { (Vict., Australien) }\end{array}$ & $\begin{array}{r}38.20^{\circ} \mathrm{S} \\
144.40^{\circ} \mathrm{E}\end{array}$ & 1975 & M. N. Clayton & \\
\hline 2017 & $\begin{array}{l}\text { Tjörnes } \\
\text { (Iceland) }\end{array}$ & $\begin{array}{l}66.13^{\circ} \mathrm{N} \\
17.07^{\circ} \mathrm{W}\end{array}$ & 1975 & K. Lüning & Lüning (1980) \\
\hline 2022 & $\begin{array}{l}\text { Muroran female } \\
\text { (Hokkaido, Japan) }\end{array}$ & $\begin{array}{r}42.19^{\circ} \mathrm{N} \\
140.59^{\circ} \mathrm{E}\end{array}$ & 1976 & M. Tatewaki & $\begin{array}{l}\text { Nakamura \& } \\
\text { Tatewaki (1975) }\end{array}$ \\
\hline 2023 & $\begin{array}{l}\text { Muroran male } \\
\text { (Hokkaido, Japan) }\end{array}$ & $\begin{array}{r}42.19^{\circ} \mathrm{N} \\
140.59^{\circ} \mathrm{E}\end{array}$ & 1976 & M. Tatewaki & $\begin{array}{l}\text { Nakamura \& } \\
\text { Tatewaki (1975) }\end{array}$ \\
\hline 2029 & $\begin{array}{l}\text { Lindesnes } \\
\text { (Norway) }\end{array}$ & $\begin{array}{r}58.00^{\circ} \mathrm{N} \\
7.05^{\circ} \mathrm{E}\end{array}$ & 1976 & K. Lüning & Lüning (1980) \\
\hline 2033 & $\begin{array}{l}\text { Santa Barbara } \\
\text { (California, USA) }\end{array}$ & $\begin{array}{r}34.25^{\circ} \mathrm{N} \\
119.41^{\circ} \mathrm{W}\end{array}$ & 1976 & K. Lüning & \\
\hline 2037 & $\begin{array}{l}\text { Bodega Bay } \\
\text { (California, USA) }\end{array}$ & $\begin{array}{c}38.19^{\circ} \mathrm{N} \\
123.05^{\circ} \mathrm{W}\end{array}$ & 1976 & K. Lüning & \\
\hline 2038 & $\begin{array}{l}\text { Monterey } \\
\text { (California, USA) }\end{array}$ & $\begin{array}{r}36.35^{\circ} \mathrm{N} \\
121.55^{\circ} \mathrm{W}\end{array}$ & 1976 & K. Lüning & \\
\hline 2045 & $\begin{array}{l}\text { Punta Baja } \\
\text { (Mexico) }\end{array}$ & $\begin{array}{r}29.59^{\circ} \mathrm{N} \\
115.50^{\circ} \mathrm{W}\end{array}$ & 1977 & J. A. West & \\
\hline 2046 & $\begin{array}{l}\text { Punta Banda } \\
\text { (Mexico) }\end{array}$ & $\begin{array}{r}31.50^{\circ} \mathrm{N} \\
116.50^{\circ} \mathrm{W}\end{array}$ & 1977 & J. A. West & Lüning (1980) \\
\hline 2125 & $\begin{array}{l}\text { Trondheim } \\
\text { (Norway) }\end{array}$ & $\begin{array}{l}63.36^{\circ} \mathrm{N} \\
10.23^{\circ} \mathrm{E}\end{array}$ & 1978 & K. Lüning & \\
\hline 2131 & $\begin{array}{l}\text { Tromsö } \\
\text { (Norway) }\end{array}$ & $\begin{array}{l}69.42^{\circ} \mathrm{N} \\
19.00^{\circ} \mathrm{E}\end{array}$ & 1978 & K. Lüning & Lüning (1980) \\
\hline 2223 & $\begin{array}{l}\text { Bamfield } \\
\text { (Vancouver Isl., USA) }\end{array}$ & $\begin{array}{r}48.50^{\circ} \mathrm{N} \\
125.08^{\circ} \mathrm{W}\end{array}$ & 1980 & K. Lüning & \\
\hline 2224 & $\begin{array}{l}\text { Hvidore } 1 \\
\text { (Denmark) }\end{array}$ & $\begin{array}{l}55.40^{\circ} \mathrm{N} \\
12.40^{\circ} \mathrm{E}\end{array}$ & 1976 & P. M. Pedersen & $\begin{array}{l}\text { Kristiansen \& } \\
\text { Pedersen (1979) }\end{array}$ \\
\hline 2227 & $\begin{array}{l}\text { Frederikssund } 1 \\
\text { (Denmark) }\end{array}$ & $\begin{array}{l}55.50^{\circ} \mathrm{N} \\
12.04^{\circ} \mathrm{E}\end{array}$ & 1976 & P. M. Pedersen & $\begin{array}{l}\text { Kristiansen \& } \\
\text { Pedersen (1979) }\end{array}$ \\
\hline 2228 & $\begin{array}{l}\text { Frederikssund } 2 \\
\text { (Denmark) }\end{array}$ & $\begin{array}{l}55.50^{\circ} \mathrm{N} \\
12.04^{\circ} \mathrm{E}\end{array}$ & 1976 & P. M. Pedersen & $\begin{array}{l}\text { Kristiansen \& } \\
\text { Pedersen (1979) }\end{array}$ \\
\hline 2229 & $\begin{array}{l}\text { Hvidore } 2 \\
\text { (Denmark) }\end{array}$ & $\begin{array}{l}55.40^{\circ} \mathrm{N} \\
12.40^{\circ} \mathrm{E}\end{array}$ & 1976 & P. M. Pedersen & $\begin{array}{l}\text { Kristiansen \& } \\
\text { Pedersen (1979) }\end{array}$ \\
\hline 2312 & $\begin{array}{l}\text { Friday Harbor } \\
\text { (Washington, USA) }\end{array}$ & $\begin{array}{r}48.33^{\circ} \mathrm{N} \\
123.04^{\circ} \mathrm{W}\end{array}$ & 1984 & K. Lüning & \\
\hline 2502 & $\begin{array}{l}\text { Lanzarote } \\
\text { (Canary Isl., Spain) }\end{array}$ & $\begin{array}{l}29.00^{\circ} \mathrm{N} \\
13.38^{\circ} \mathrm{W}\end{array}$ & 1985 & P. M. Pedersen & \\
\hline 2503 & $\begin{array}{l}\text { Sarqaq } \\
\text { (Greenland) }\end{array}$ & $\begin{array}{l}64.25^{\circ} \mathrm{N} \\
50.17^{\circ} \mathrm{W}\end{array}$ & 1973 & P. M. Pedersen & Pedersen (1980) \\
\hline 2524 & $\begin{array}{l}\text { Thessaloniki } \\
\text { (Greece) }\end{array}$ & $\begin{array}{l}40.38^{\circ} \mathrm{N} \\
22.58^{\circ} \mathrm{E}\end{array}$ & 1985 & S. Orfanidis & \\
\hline
\end{tabular}


of these experiments. Each temperature test lasted two weeks. Afterwards, the VSES medium in the test tubes was replaced by autoclaved PES, and the tubes were transferred for post-cultivation to suitable growing conditions, i. e. $10^{\circ} \mathrm{C}, \mathrm{LD}$. Four weeks later, the survival capacity of the germlings was qualitatively analyzed by discriminating whether all plants, or only a few plants were alive, or all plants dead. The important criterion for survival was the presence of multicellular plants (microthalli or macrothalli) which had formed during post-cultivation. In doubtful cases, another four weeks of post-cultivation followed, with prior renewal of PES. The temperature test for each isolate was performed at least twice.

\section{RESULTS}

\section{Daylength dependence of upright thallus formation}

The isolates from different localities indicated in Table 2 and Table 3 were subjected to the 15 temperature/daylength regimes in order to determine their photoperiodic or day-neutral character. The experiments were divided into two groups of test strains. Group A included all isolates of the culture collection with unknown reaction pattern concerning photoperiod. Group B included several isolates that had known, but previously unquantified day-neutral reaction patterns (Kristiansen \& Pedersen, 1979; Nakamura \& Tatewaki, 1975), and also several known photoperiodic isolates (Lüning, 1980). For Danish strains one quantification already exists (Kristiansen, 1984); this isolate was not included in the present investigation. The photoperiodic isolates were incorporated for two reasons: (a) to test whether the many years of culturing had influenced reaction patterns, (b) to test the correct functioning of the light cabinets providing the different dayléngth regimes.

Gro u p A (Table 2). In this group, six day-neutral strains were detected (Isle of Man, Thessaloniki, Friday Harbor, Bodega Bay, Monterey, and Santa Barbara), and two photoperiodic strains (Lanzarote; Punta Baja). The isolates from Friday Harbor, Bodega Bay and Santa Barbara all exhibited a similar reaction pattern with almost $100 \%$ formation of upright thalli under all test conditions except $20^{\circ} \mathrm{C}$. The Thessaloniki strain reacted similarly but was tested only once at $10^{\circ} \mathrm{C}$. The strains from Friday Harbor and Santa Barbara behaved as strains "with fast differentiation", as termed by Kristiansen \& Pedersen (1979). These isolates did not form crusts but only few-celled prostrate systems quickly giving rise to upright thalli.

In contrast to the strains of Friday Harbor, Bodega, Santa Barbara and Thessaloniki, the day-neutral Monterey isolate showed a very reduced response in regard to the formation of upright thalli, which were produced in low numbers at higher temperatures only $\left(15^{\circ} \mathrm{C}\right.$ and $\left.20^{\circ} \mathrm{C}\right)$. Only this strain formed upright thalli at $20^{\circ} \mathrm{C}$. For all other tested isolates (Tables 2-3) there is a temperature block for upright thallus development at $20^{\circ} \mathrm{C}$, independent of their daylength response.

The day-neutral Isle of Man isolate also showed some pecularities. In the first test, there was an almost $100 \%$ upright thallus formation under all experimental conditions. Strikingly, two different morphological types of microthalli were present, (a) mainly normal ralfsioid crusts all giving rise to upright plants, and (b) a few filamentous cushionlike microthalli without any macrothallus formation. In the second test, these filamentous microthalli became more abundant than the crusts and correspondingly fewer upright 


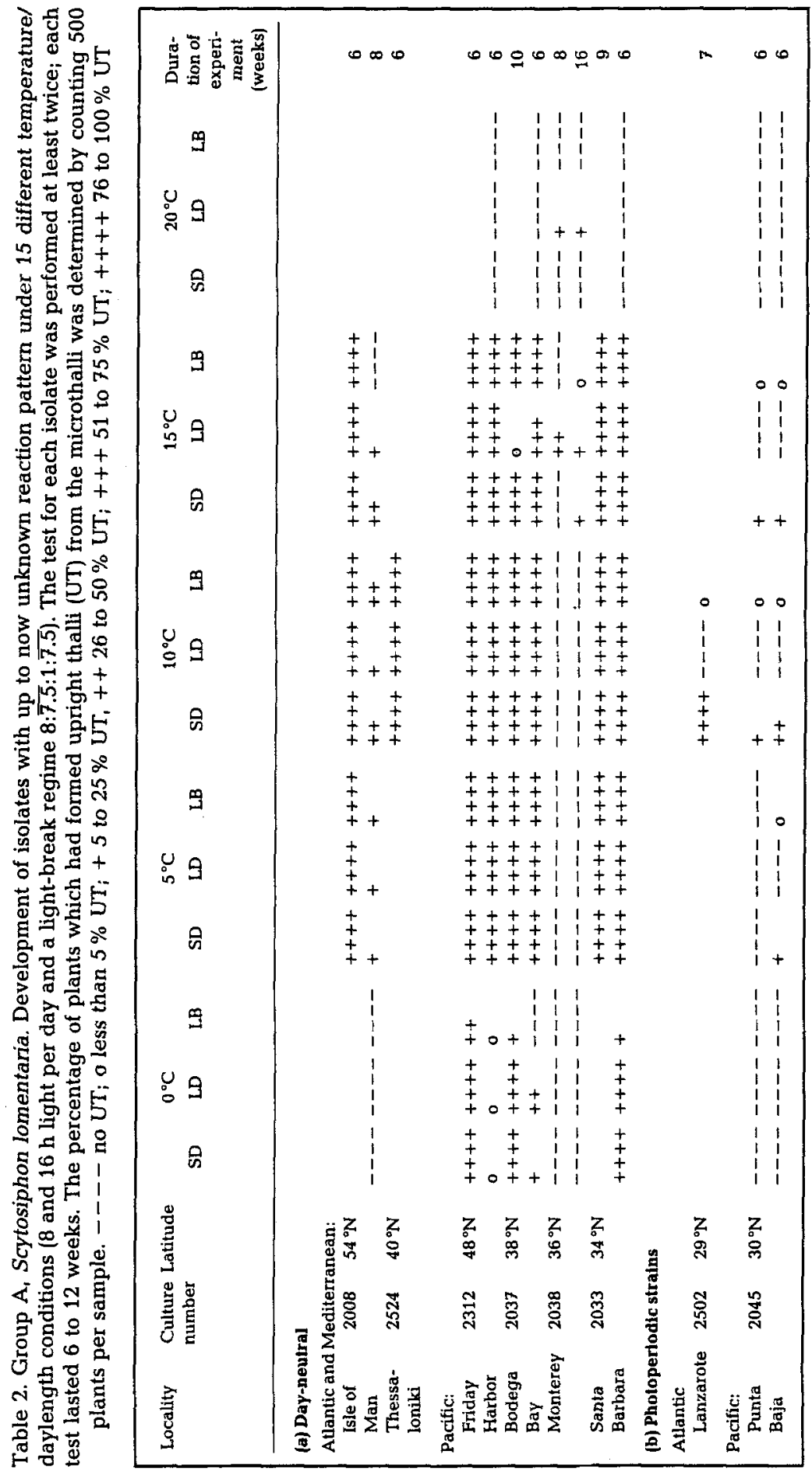




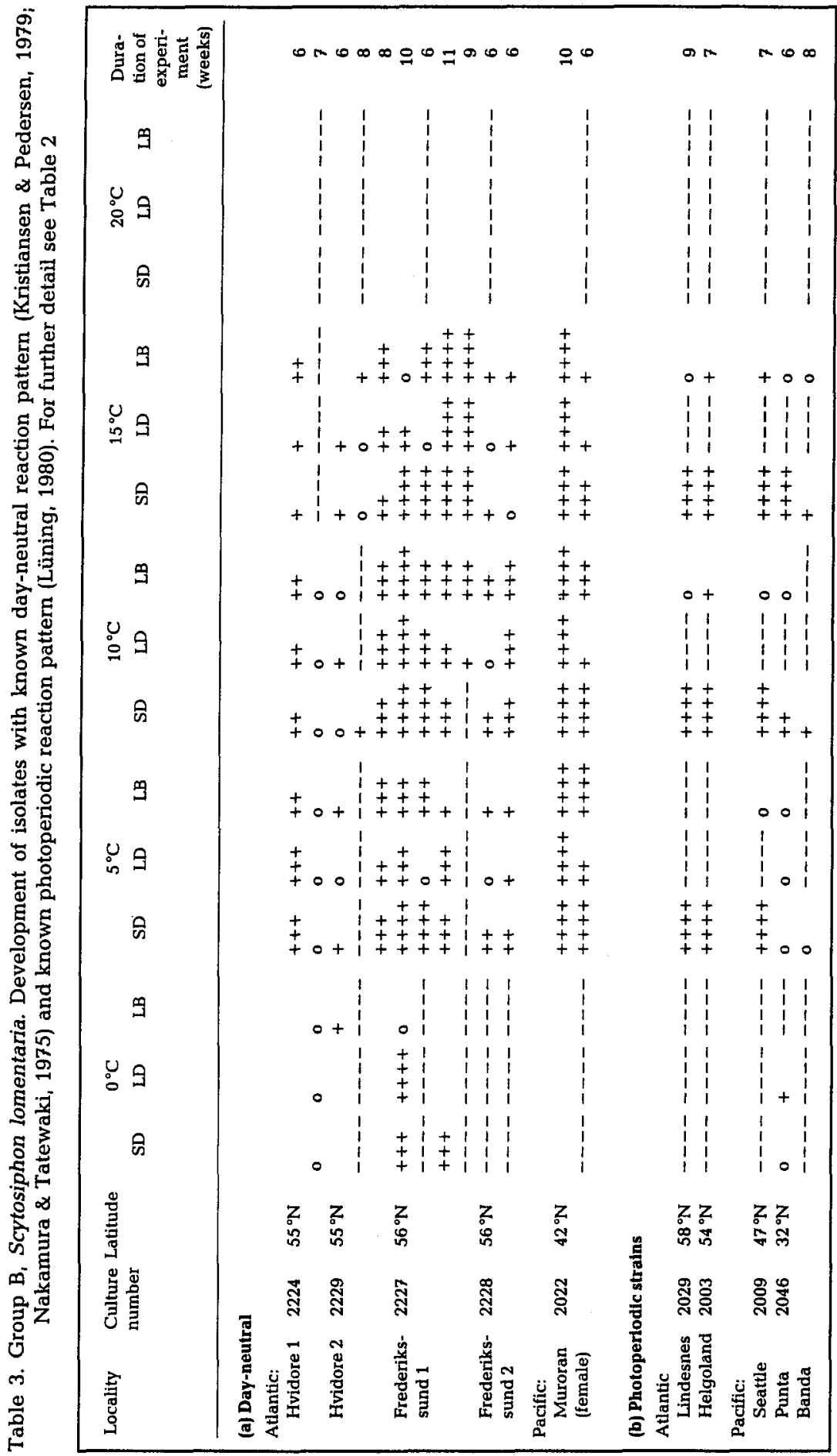


plants were formed under all test conditions. To follow the further development of these morphological forms, one filamentous and one crustose microthallus was isolated and separately cultivated at $10^{\circ} \mathrm{C}$, under short-day conditions. The filamentous microthallus developed uniseriate plurilocular zoidangia; the zoids gave rise to a second generation of filamentous microthalli, again unable to exhibit upright plants. The crustose microthallus gave rise to several upright plants vegetatively; the zoids derived from these upright plants formed mainly ralfsioid crusts with upright thalli but also a few filamentous microthalli without upright thalli. This reaction pattern of both morphological forms was observed during two successive generations. Two years later, it was no longer possible to induce the Isle of Man isolate to form erect thalli; instead, it reproduced its filamentous cushions via plurilocular zoidangia.

The Punta Baja isolate, which proved to be photoperiodic, showed reduced upright thallus formation similar to that of the day-neutral Monterey isolate. Only 5-25\% of the Punta Baja plants formed upright thalli under inductive conditions. The photoperiodic Lanzarote isolate, which was tested only once at $10^{\circ} \mathrm{C}$, showed an expected $100 \%$ formation of upright thalli under short-day conditions.

Group B (Table 3). The present investigation confirmed the qualitative results of former workers (Nakamura \& Tatewaki, 1975; Kristiansen \& Pedersen, 1979) with respect to the day-neutral behaviour of the isolates from Frederikssund 1, Frederikssund 2, Hvidore 1, Hvidore 2, Muroran (female). However, there was a high variability in the percentage of upright thalli formed during repeated experiments on the Danish strains. The Muroran (female) isolate showed the same rapid way of development as mentioned above for the Friday Harbor and Santa Barbara isolates. The Muroran (male) culture was also investigated but did not respond with upright thalli formation under any test conditions although it has formerly done so (see Nakamura \& Tatewaki, 1975).

The known photoperiodic strains of this group, except the Punta Banda isolate, reacted in the expected manner demonstrating the persistence of the photoperiodic reaction after 10 years of cultivation. Specifically, these isolates exhibited about $100 \%$ upright thalli under short-day conditions only, $0 \%$ upright thalli under long-day conditions, and less than $5 \%$ upright plants under light-break conditions. The Punta Banda isolate still showed short-day response but the number of upright plants formed was reduced, compared to former results (see Lüning, 1980).

\section{Temperature-dependent formation of upright thalli}

The formation of upright thalli was enhanced at intermediate temperatures as shown in Figure 1 for four isolates. This was valid for photoperiodic and day-neutral strains, and was found to be a general tendency among all strains investigated. The first thalli were always visible at $15^{\circ} \mathrm{C}$ and/or $10^{\circ} \mathrm{C}$. A few weeks later, similar high percentages of upright thalli were evident also at lower temperatures at $5{ }^{\circ} \mathrm{C}$ and/or $0{ }^{\circ} \mathrm{C}$.

In contrast to the variability of results at $0^{\circ} \mathrm{C}$, a temperature of $20^{\circ} \mathrm{C}$ was consistently limiting for macrothallus formation with the exception of the Monterey isolate. The occurrence of upright thalli at $0^{\circ} \mathrm{C}$ varied from test to test and could not be consistently linked with the duration of the experiments, as evident for the strains from Friday Harbor (Table 2) and Punta Banda (Table 3). Whenever upright thalli were formed at $0{ }^{\circ} \mathrm{C}$, this was usually evident after 6 weeks. However, a later observation on the Helgoland strain 


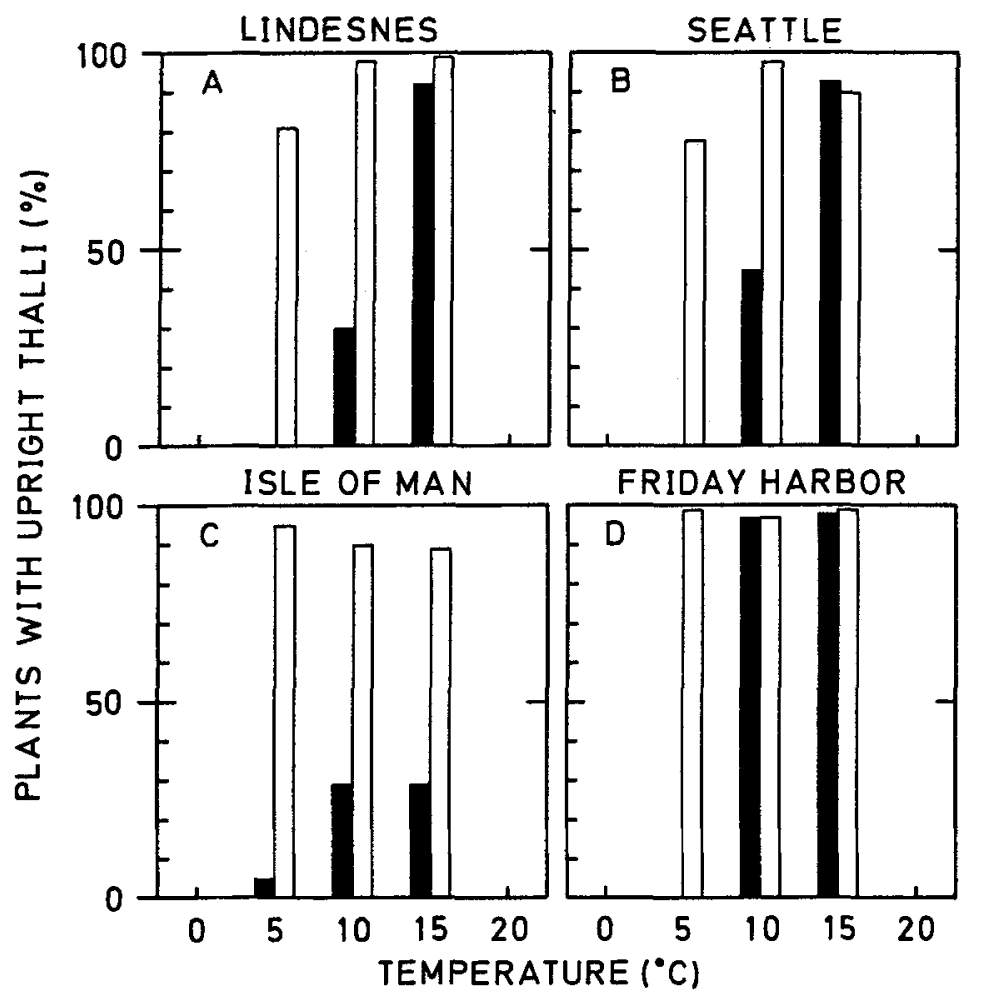

Fig. 1. Temperature-dependent upright thallus (UT) formation in Scytosiphon lomentaria. Only UT formation in short-day conditions was considered. (A) and (B) Photoperiodic strains. (C) and (D) Dayneutral strains. Black bars indicate percentage of plants with UT after 4 weeks; white bars indicate percentage of plants with UT after 6-7 weeks

indicated the ability to form stunted upright thalli at $0{ }^{\circ} \mathrm{C}$, short-day conditions, after a prolonged induction period of 12 weeks.

\section{Temperature tolerance}

Regarding the question of possible intraspecific temperature ecotypes, 19 isolates from different localities of Scytosiphon lomentaria were tested for their upper temperature tolerance (Table 4). All strains survived $27^{\circ} \mathrm{C}$ without damage, $28^{\circ} \mathrm{C}$ being endured by all but one strain. The Santa Barbara strain survived $27^{\circ} \mathrm{C}$ only, and two other strains (Thessaloniki and Muroran, female) were damaged at $28^{\circ} \mathrm{C}$. At $29^{\circ} \mathrm{C}$ the survival capacity was reduced in most strains, with only few plants alive after post-cultivation. Only the strains from Frederikssund 2 and Hvidore 1 endured this temperature without damage during repeated experiments. However, at $30^{\circ} \mathrm{C}$ these strains died as did all the others. 
Table 4. Upper survival temperatures of isolates from different localities of Scytosiphon lomentaria. One-day old germlings derived from zoids of upright thalli were subjected for 2 weeks to the experimental temperatures. Each test was performed at least twice. The results were obtained after 4 to 8 weeks of postcultivation in $10^{\circ} \mathrm{C}$, long-day conditions. The strains are listed from north to south according to their collection site. The Mediterranean strains are included in the Atlantic strains. $\times \times$ all plants alive; ** only a few plants alive; -- all plants dead

\begin{tabular}{|c|c|c|c|c|c|c|}
\hline \multirow[t]{2}{*}{ Locality } & \multirow{2}{*}{$\begin{array}{l}\text { Culture } \\
\text { number }\end{array}$} & \multicolumn{5}{|c|}{ Experimental temperatures $\left({ }^{\circ} \mathrm{C}\right)$} \\
\hline & & 26 & 27 & 28 & 29 & 30 \\
\hline \multicolumn{7}{|l|}{ Atlantic } \\
\hline \multirow[t]{2}{*}{ Tromsö } & 2131 & $x \times$ & $x \times$ & $x \times$ & -- & -- \\
\hline & & $x \times$ & $x \times$ & $x \times$ & -- & -- \\
\hline \multirow[t]{2}{*}{ Tjörnes } & 2017 & $x \times$ & $x \times$ & $x \times$ & -- & -- \\
\hline & & $x \times$ & $x \times$ & $x \times$ & $* *$ & -- \\
\hline \multirow[t]{2}{*}{ Sarqaq } & 2503 & $x \times$ & $x \times$ & $x \times$ & -- & -- \\
\hline & & $x \times$ & $x \times$ & $* *$ & -- & -- \\
\hline \multirow[t]{3}{*}{ Trondheim } & 2125 & $x \times$ & $x \times$ & $x \times$ & -- & -- \\
\hline & & $x \times$ & $x \times$ & $x \times$ & $* *$ & -- \\
\hline & & $x \times$ & $x \times$ & $x \times$ & $x$ & -- \\
\hline \multirow[t]{2}{*}{ Lindesnes } & 2029 & $x \times$ & $x \times$ & $x \times$ & :** & -- \\
\hline & & $x \times$ & $x \times$ & $x \times$ & $* *$ & -- \\
\hline \multirow[t]{2}{*}{ Frederikssund 2} & 2228 & $x \times$ & $x \times$ & $x \times$ & $x \times$ & -- \\
\hline & & $x \times$ & $x x$ & $x \times$ & $x \times$ & -- \\
\hline \multirow[t]{2}{*}{ Hvidore } & 2224 & $x \times$ & $x x$ & $x \times$ & $x \times$ & -- \\
\hline & & $x \times$ & $x x$ & $x \times$ & $x \times$ & -- \\
\hline \multirow{3}{*}{ Helgoland } & 2003 & $x \times$ & $x \times$ & $x \times$ & $* 2$ & -- \\
\hline & & $x \times$ & $x \times$ & $x \times$ & $x \neq$ & -- \\
\hline & & $x \times$ & $x \times$ & $x \times$ & trth & -- \\
\hline \multirow[t]{2}{*}{ Rovinj } & 2011 & $x \times$ & $x x$ & $x \times$ & $* *$ & -- \\
\hline & & $x \times$ & $x x$ & $x \times$ & $x \rightarrow x$ & -- \\
\hline \multirow[t]{2}{*}{ Thessaloniki } & 2524 & $x \times$ & $x \times$ & -- & -- & -- \\
\hline & & $x \times$ & $x \times$ & $* *$ & -- & -- \\
\hline \multirow[t]{3}{*}{ Lanzarote } & 2502 & $x \times$ & $* *$ & $x *$ & -- & -- \\
\hline & & $x \times$ & $x \times$ & $4 *$ & -- & -- \\
\hline & & $x \times$ & $x x$ & $x \times$ & $x \times$ & -- \\
\hline \multicolumn{7}{|l|}{ Pacific } \\
\hline \multirow[t]{3}{*}{ Bamfield } & 2223 & $x \times$ & $x \times$ & $x \times$ & $* *$ & -- \\
\hline & & $x \times$ & $x \times$ & $x \times$ & -- & -- \\
\hline & & $x \times$ & $x \times$ & $x \times$ & $x \times$ & -- \\
\hline \multirow[t]{2}{*}{ Friday Harbor } & 2312 & $x \times$ & $x \times$ & $\times x$ & -- & -- \\
\hline & & $x \times$ & $x \times$ & $x \times$ & -- & -- \\
\hline \multirow[t]{3}{*}{ Seattle } & 2009 & $x \times$ & $x \times$ & $x \times$ & $* x$ & -- \\
\hline & & $x \times$ & $x \times$ & $* *$ & -- & -- \\
\hline & & & $x \times$ & $x \times$ & -- & -- \\
\hline \multirow[t]{2}{*}{ Muroran (female) } & 2022 & $x \times$ & $2 *$ & -- & -- & -- \\
\hline & & $x \times$ & $x \times$ & $*$ & -- & -- \\
\hline \multirow[t]{2}{*}{ Bodega Bay } & 2037 & $x \times$ & $x \times$ & $x \times$ & -- & -- \\
\hline & & $x \times$ & $x \times$ & $x \times$ & -- & -- \\
\hline Santa Barbara & 2033 & $x \times$ & $x \times$ & -- & -- & -- \\
\hline & & $x \times$ & $x \times$ & -- & -- & -- \\
\hline Punta Banda & 2046 & $x \times$ & $x \times$ & $x \times$ & $x \times$ & -- \\
\hline & & $x \times$ & $x \times$ & $x \times$ & $* *$ & -- \\
\hline & & & $x \times$ & $x \times$ & -- & -- \\
\hline Punta Baja & 2045 & $x \times$ & $x x$ & $x \times$ & ** & -- \\
\hline & & $x \times$ & $x \times$ & $x x$ & $4 *$ & -- \\
\hline & & & $x \times$ & $x \times$ & -- & -- \\
\hline
\end{tabular}




\section{Observations on reproduction of the microthallus}

During the experiments on daylength responses, unilocular zoidangia were never found, with the exception of the isolate from Australia (Flinders) which once formed unilocular zoidangia in $5^{\circ} \mathrm{C}$, short-day conditions. In contrast, uniseriate plurilocular zoidangia were often found in all isolates with filamentous microthalli, i. e. in the isolates from Flinders 1, Isle of Man and Tromsö.

However, about one year later abundant unilocular zoidangia were detected in several strains of the culture collection which had been transferred from $15^{\circ} \mathrm{C}$, long-day to $15^{\circ} \mathrm{C}$, short-day conditions two months before. Similarly, several other findings of unilocular zoidangia during the temperature test experiments related only to cultures which had been in short-day conditions for some time. In some isolates, the formation of unilocular zoidangia was observed for the first time, i. e. in the isolates from Helgoland, Punta Baja, Frederikssund 1, Hvidore 1, Hvidore 2, and Lanzarote. In two cases, the simultaneous formation of plurilocular and unilocular zoidangia by microthalli was observed, i. e. in the isolate Flinders 1 and another Flinders isolate not listed in Table 1 (complanate, male, No. 2240).

\section{DISCUSSION}

The discovery of six day-neutral and two new photoperiodic isolates of Scytosiphon lomentaria demonstrates that the occurrence of day-neutral as well as photoperiodic strains is a common phenomenon in this species throughout its distribution area. The temperature reaction patterns of both day-neutral and photoperiodic strains do not show striking differences, but the inherent temperature reactions seem to be sufficient to trigger the seasonal appearance of many of the day-neutral strains, as will be discussed below.

The geographical origin and the photoperiodic or day-neutral behaviour of all the strains of $S$. lomentaria that have been investigated up to now by different authors including the results of this investigation - are illustrated in Figure 2. It is evident that the number of day-neutral strains is equivalent to the number of photoperiodic strains. The supposition expressed by Correa et al. (1986) that complanate forms of S. lomentaria might represent prime candidates for day-neutral behaviour ("difference in physiology coincides with difference in the morphology") cannot be maintained, as the day-neutral reaction pattern is established in cylindrical as in complanate forms of $S$. lomentaria (Clayton, 1976a; 1976b; Pedersen, 1980; Kristiansen, 1984; Correa et al., 1986; this investigation). $S$. lomentaria is the only macroalgal species so far detected which exhibits both day-neutral and photoperiodic ecotypes - a phenomenon well-known in higher plants (McMillan, 1974; Salisbury, 1981). This may be due to the lack of other detailed intraspecific investigations of photoperiodic algae. Only for Rhodochorton purpureum have photoperiodic ecotypes been described, in this case with respect to tetrasporangium formation (Dring \& West, 1983).

The variability in response to photoperiod in $S$. lomentaria is not easily interpreted ecologically but it does indicate that the life history is not only controlled photoperiodically. Hence, if the photoperiodic control mechanism itself (short-day requirement) is lacking (day-neutral strains), the process under photoperiodic control (upright thallus formation) can be promoted under the appropriate temperature conditions (at about 


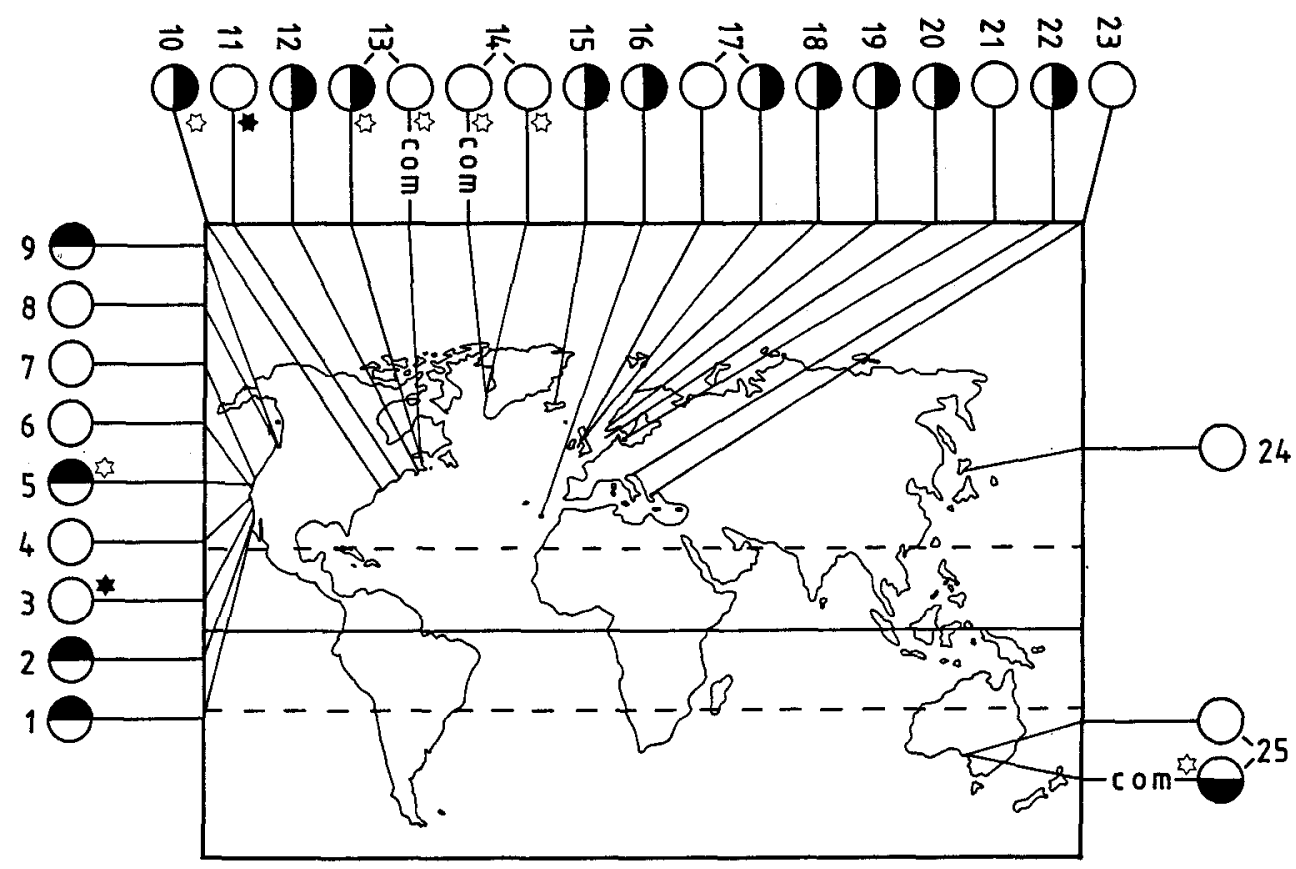

day-neutral photoperiodic

Fig. 2. Photoperiodic and day-neutral isolates of different localities of Scytosiphon lomentaria. This illustration includes all available data from literature and from the present investigation. Closed asterix: strains for which photoperiodic or day-neutral behaviour of upright thallus formation was not quantitatively investigated, but concluded from the season of occurrence indicated in the corresponding publication. Open asterix: no light-break was used in the corresponding publication. com complanate form of $S$. lomentaria. Localities: 1 - Punta Baja, 2 - Punta Banda, 3 - San Diego, 4 Santa Barbara, 5 - San Francisco, 6 - Monterey, 7 - Bodega Bay, 8 - Friday Harbor, 9 - Seattle, 10 Wachapreague, 11 - Canoe Beach Cove, 12 - Halifax, 13 - Pomquet Harbour, 14 - Godhavn (complanate form) and Sarqaq, 15 - Tjörnes, 16 - Lanzarote, 17 - Isle of Man, 18 - Tromsö, 19 Lindesnes, 20 - Helgoland, 21 - Denmark, 22 - Rovinj, 23 - Thessaloniki, 24 - Muroran, 25 Flinders. Sources: 5 - Wynne (1969); 10 - Rhodes \& Connell (1973); 25 - Clayton (1976b); 3 Emerson \& Zedler (1978); 11 - Lubchenco \& Cubit (1980); 2, 9, 12, 15, 17, 18, 19, 20, 22, 25 - Lüning (1980); 14 - Pedersen (1980); 21 - Kristiansen (1984); 13 - Correa et al. (1986); 1, 4, 6, 7, 8, 17, 21, 23, 24 - this investigation

$0-20^{\circ} \mathrm{C}$ ) at any daylength. As these "appropriate temperature conditions" can differ among isolates from different localities, they could represent a second independent regulator. However, a clear relationship between the latitude of the collection site of a strain and the temperatures allowing upright thallus formation postulated by Lüning (1980) should be regarded with reservation. It becomes evident from a comparison of all available data from literature (Table 5) that isolates from similar latitudes may exhibit contrasting temperature responses; e.g. upright thallus formation in a strain from Tjörnes, northern Iceland, was inhibited in this respect at $15^{\circ} \mathrm{C}$ (Lüning, 1980) but not in an isolate from Sarqaq, southwestern Greenland (Pedersen, 1980). The comparison of the 
Table 5. Comparison of all available data from literature concerning upright thallus formation, under different temperatures, of isolates of Scytosiphon lomentaria. cyl cylindrical form of $S$. lomentaria, com complanate form of $S$. lomentaria, +++ full upright plant formation, $+/-$ reduced upright plant formation, - - no upright plant formation

\begin{tabular}{|c|c|c|c|c|c|c|c|}
\hline Locality & & Latitude & $5^{\circ}$ & $10^{\circ}$ & $15^{\circ}$ & $20^{\circ} \mathrm{C}$ & Reference \\
\hline $\begin{array}{l}\text { Punta Banda } \\
\text { (Mexico) }\end{array}$ & cyl & $32^{\circ} \mathrm{N}$ & +++ & +++ & +++ & +++ & Lüning (1980) \\
\hline $\begin{array}{l}\text { Virginia } \\
\text { (USA) }\end{array}$ & cyl & $37^{\circ} \mathrm{N}$ & & & & $+++^{*}$ & $\begin{array}{l}\text { Rhodes \& } \\
\text { Conell (1973) }\end{array}$ \\
\hline $\begin{array}{l}\text { Flinders, Vict. } \\
\text { (Australia) }\end{array}$ & cyl & $38^{\circ} \mathrm{S}$ & +++ & +++ & +++ & +++ & Lüning (1980) \\
\hline $\begin{array}{l}\text { Muroran } \\
\text { (Hokk., Japan) }\end{array}$ & cyl & $42^{\circ} \mathrm{N}$ & & & $+++\cdots *$ & $---\cdots$ & $\begin{array}{l}\text { Nakamura \& } \\
\text { Tatewaki (1975) }\end{array}$ \\
\hline $\begin{array}{l}\text { Halifax } \\
\text { (Nova Sc., USA) }\end{array}$ & cyl & $45^{\circ} \mathrm{N}$ & +++ & +++ & +++ & +++ & Lüning (1980) \\
\hline $\begin{array}{l}\text { Pomquet Harbour } \\
\text { (Nova Sc., USA) }\end{array}$ & com & $45^{\circ} \mathrm{N}$ & +++ & +++ & $+1-$ & --- & $\begin{array}{l}\text { Correa et al. } \\
\text { (1986) }\end{array}$ \\
\hline $\begin{array}{l}\text { Rovinj } \\
\text { (Yugoslavia) }\end{array}$ & $\mathrm{cyl}$ & $45^{\circ} \mathrm{N}$ & +++ & +++ & +++ & +++ & Lüning (1980) \\
\hline $\begin{array}{l}\text { Seattle } \\
\text { (Wash., USA) }\end{array}$ & cyl & $48^{\circ} \mathrm{N}$ & +++ & +++ & +++ & +++ & Lüning (1980) \\
\hline $\begin{array}{l}\text { Helgoland } \\
\text { (West Germany) }\end{array}$ & cyl & $54^{\circ} \mathrm{N}$ & $+t+$ & +++ & +++ & $+1-$ & Lüning (1980) \\
\hline $\begin{array}{l}\text { Port Erin } \\
\text { (Isle of Man) }\end{array}$ & cyl & $54^{\circ} \mathrm{N}$ & +++ & +++ & +++ & +++ & Lüning (1980) \\
\hline $\begin{array}{l}\text { Lindesnes } \\
\text { (Norway) }\end{array}$ & cyl & $58^{\circ} \mathrm{N}$ & +++ & +++ & +++ & $+1-$ & Lüning (1980) \\
\hline $\begin{array}{l}\text { Sarqaq } \\
\text { (Greenland) }\end{array}$ & cyl & $64^{\circ} \mathrm{N}$ & & & +++ & & Pedersen (1980) \\
\hline $\begin{array}{l}\text { Tjörnes } \\
\text { (Iceland) }\end{array}$ & cyl & $66^{\circ} \mathrm{N}$ & +++ & +++ & -- & --- & Lüning (1980) \\
\hline $\begin{array}{l}\text { Tromsö } \\
\text { (Norway) }\end{array}$ & cyl & $69^{\circ} \mathrm{N}$ & +++ & --- & --- & --- & Lüning (1980) \\
\hline $\begin{array}{l}\text { Godhavn } \\
\text { (Greenland) }\end{array}$ & com & $69^{\circ} \mathrm{N}$ & & & +++ & & Pedersen (1980) \\
\hline
\end{tabular}

isolates from Pomquet Harbour, Nova Scotia (Correa et al., 1986), and Halifax, Nova Scotia (Lüning, 1980) renders a similar example. In the case of Pomquet Harbour/Halifax the complanate form of $S$. lomentaria is compared with the cylindrical form which might cause a difference as well. The isolates from Punta Banda, Seattle, Helgoland and Lindesnes, which were more or less able to form upright thalli at $20^{\circ} \mathrm{C}$ in the investigation by Lüning (1980) (Table 5), were completely inhibited at $20^{\circ} \mathrm{C}$ during this investigation (Table 3). One reason for the differing results could be the temperature deviation of $+1-2{ }^{\circ} \mathrm{C}$ in the $20^{\circ} \mathrm{C}$ culture room instead of $+1-1^{\circ} \mathrm{C}$ in the investigation of Lüning (1980).

The photoperiodic $S$. lomentaria strain from Rovinj investigated by Lüning (1980) was one of the best examples demonstrating the dominant regulative effect of photo- 
period in contrast to temperature in the natural habitat. The Rovinj isolate came from a locality where summer temperatures are sufficiently high $\left(20^{\circ} \mathrm{C}\right)$ to block the upright thallus formation. However, these temperatures occurred three months after the critical daylength of $10 \mathrm{~h}$ was exceeded and had inhibited the upright thallus formation. The Thessaloniki strain (Greece, $40.4^{\circ} \mathrm{N}$ ) which was investigated here, is comparable to the Rovinj strain (Yugoslavia, $45^{\circ} \mathrm{N}$ ) in that its habitat has wide temperature fluctuations during the year and the alga has a pronounced late winter/spring occurrence (Orfanidis, pers. comm.); however, this strain was shown to be day-neutral. Possibly, the seasonality of the Thessaloniki isolate is mainly triggered by temperature. The recent work of Correa et al. (1986) stresses the same point. At Nova Scotia, the absence of macrothalli in late summer of both the complanate, day-neutral form of $S$. lomentaria and the cylindrical, photoperiodic form seems to be due to high water temperatures in the first case and due to non-inductive daylength in the latter case. In Danish waters, the period of occurrence of $S$. lomentaria may be prolonged by unusually low summer temperatures (Kristiansen, 1981).

As $S$. lomentaria is an intertidal or tide-pool species in many localities, it often has to endure a wider range of temperatures than would be indicated by mean or maximum/ minimum mean sea surface temperatures. Even on the Alaskan Peninsula the daily temperature course in tidal pools may range from about $10^{\circ} \mathrm{C}$ to a maximum of $35^{\circ} \mathrm{C}$ in summer (Biebl \& McRoy, 1971). In shallow lagoons, the water temperature is correlated with mean air temperature (Barnes, 1977). The importance of daily temperature fluctuations was demonstrated by Breemann et al. (1984) for Rhodochorton purpureum whose tetrasporogenesis is inhibited by high temperatures. In this case, a regime consisting of high blocking temperatures applied for part of the day and optimal temperatures applied for the rest of the day considerably inhibited tetrasporogenesis. Corresponding investigations are lacking for $S$. lomentaria, but such investigations might cast light upon the strict seasonality of many of those day-neutral strains living in areas without inhibiting high summer surface temperatures. However, temperature is not the only factor determining the appearance of day-neutral strains of $S$. lomentaria in nature (see Kristiansen \& Pedersen, 1979; Lubchenco \& Cubit, 1980; Dethier, 1981; Littler \& Littler, 1983; Kristiansen, 1984).

The test on upper temperature tolerance of the 19 isolates from different localities clarifies that there is a $1{ }^{\circ} \mathrm{C}$ variability which cannot be exactly recorded by the method used, because in several cases the highest survival temperature differed by $1{ }^{\circ} \mathrm{C}$ in repeated experiments. With this in mind, the $2{ }^{\circ} \mathrm{C}$ difference evident among all of the tested isolates (see Table 4) should be judged carefully, especially as only one strain (Santa Barbara) did not survive $28^{\circ} \mathrm{C}$. Hence, $S$. lomentaria is characterized by a rather uniform survival limit of $28-29^{\circ} \mathrm{C}$ after a heat stress period of two weeks. This temperature correlates well with the isotherms of oceanic surface water of the southern distribution boundary (see van den Hoek, 1982). No temperature ecotypes were detected, in contrast to the known photoperiodic ecotypes. However, only upper temperature tolerance was tested in the present investigation. Hence, it remains unknown whether other temperature characteristics of $S$. lomentaria are as conservative, until detailed investigations, for example on temperature-dependent growth rates and reproduction in isolates from different localities, have been performed. 
Acknowledgements. I am very grateful to Dr. K. Lüning for critical advice during the course of this work. Thanks are due to Dr. P. M. Pedersen for the isolates from Lanzarote and Sarqaq, and to S. Orfanidis for the Thessaloniki isolate. Valuable comments on the manuscript were given by Dr. K. Lüning, Prof. G. Russell, Dr. A. M. Breeman and Dr. I. Novaczek, Dr. Aa. Kristiansen and Dr. P. M. Pedersen. I wish to thank the Biologische Anstalt Helgoland for laboratory space and working facilities. Part of this research was undertaken from August 1984 to July 1985 to complete the Diploma-degree course at the University of Hamburg. The rest of the work was carried out during 1986 with the aid of a fellowship from the Biologische Anstalt Helgoland.

\section{LITERATURE CITED}

Barnes, R. S. K. (Ed.), 1977. The coastline. Wiley, Chichester, $356 \mathrm{pp}$.

Biebl, R. \& McRoy, C. P., 1971. Plasmatic resistance and rate of respiration and photosynthesis of Zostera marina at different salinities and temperatures. - Mar. Biol. 8, 48-56.

Bolton, J. J., 1983. Ecoclinal variation in Ectocarpus siliculosus (Phaeophyceae) with respect to temperature growth optima and survival limits. - Mar. Biol. 73, 131-138.

Breeman, A. M., Bos, S., Essen, S. van \& Mulekom, L. L. van, 1984. Light-dark regimes in the intertidal zone and tetrasporangial periodicity in the red alga Rhodochorton purpureum. Helgoländer Meeresunters. 38, 365-387.

Clayton, M. N., 1976a. The morphology, anatomy and life history of a complanate form of Scytosiphon lomentaria (Scytosiphonales, Phaeophyta) from southern Australia. - Mar. Biol. 38, 201-208.

Clayton, M. N., 1976b. Complanate Scytosiphon lomentaria (Lyngbye) J. Agardh (Scytosiphonales: Phaeophyta) from southern Australia: The effects of season, temperature, and daylength on the life history. - J. exp. mar. Biol. Ecol. 25, 187-198.

Clayton, M. N., 1978. Morphological variation and life history in cylindrical forms of Scytosiphon lomentaria (Scytosiphinaceae: Phaeophyta) from southern Australia. - Mar. Biol. 47, 349-357.

Correa, J., Novaczek, I. \& McLachlan, J., 1986. Effect of temperature and daylength on morphogenesis of Scytosiphon lomentaria (Scytosiphonales, Phaeophyta) from eastern Canada. Phycologia 25, 469-475.

Dethier, M. N., 1981. Heteromorphic algal life histories: The seasonal pattern and response to herbivory of the brown crust, Ralfsia californica. - Oecologia 46, 333-339.

Dring, M. J. \& West, J. A., 1983. Photoperiodic control of tetrasporangium formation in the red alga Rhodochorton purpureum. - Planta 159, 143-150.

Emerson, S. E. \& Zedler, J. B., 1978. Recolonization of intertidal algae; An experimental study. - Mar. Biol. 44, 315-324.

Guiry, M. D. \& Cunningham, E. M., 1984. Photoperiodic and temperature responses in the reproduction of north-eastern Atlantic Gigartina acicularis (Rhodophyta: Gigartinales). - Phycologia 23, 357-367.

Hoek, C. van den, 1982. The distribution of benthic marine algae in relation to the temperature regulation of their life histories. - Biol. J. Linn. Soc. Lond. 18, 81-144.

Kristiansen, Aa., 1981. Seasonal occurrence of Scytosiphon Iomentaria (Scytosiphonales, Fucophyceae) in relation to environmental factors. - Proc. int. Seaweed Symp., 10, 321-326.

Kristiansen, Aa., 1984. Experimental field studies on the ecology of Scytosiphon lomentaria (Fucophyceae, Scytosiphonales) in Denmark. - Nord. J. Bot. 4, 719-724.

Kristiansen, Aa. \& Pedersen, P. M., 1979. Studies on life history and seasonal variation of Scytosiphon lomentaria (Fucophyceae, Scytosiphonales) in Denmark. - Bot. Tidsskr. 74, 31-56.

Littler, M. M. \& Littler, D. S., 1983. Heteromorphic life-history strategies in the brown alga Scytosiphon lomentaria (Lyngb.) Link. - J. Phycol. 19, 425-431.

Lubchenco, J. \& Cubit, J., 1980. Heteromorphic life histories of certain marine algae as adaptations to variations in herbivory. - Ecology $61,676-687$.

Lüning, K., 1980. Control of algal life-history by daylength and temperature. In: The shore environment. Ed. by J. H. Price, D. E. G. Irvine \& W. F. Farnham. Acad. Press, Lond, 2, 915-945.

Lüning, K, Guiry, M. D. \& Masuda, M., 1987. Upper temperature tolerance of North Atlantic and North Pacific geographic isolates of the red alga Chondrus. - Helgoländer Meeresunters. 41, 297-306 
McMillan, C., 1974. Photoperiodic responses of Xanthium strumarium L. (Compositae) introduced and indigenous in Eastern Asia. - Bot. Mag. Tokyo 87, 261-269.

Meer, J. P. von der, 1981. The inheritance of spontaneous pigment mutations in Chondrus crispus Stackh. (Rhodophyceae). - Proc. Nova Scotian Inst. Sci. 31, 187-192.

Nakamura, Y. \& Tatewaki, M., 1975. The life history of some species of the Scytosiphonales. - Scient. Pap. Inst. algol. Res. Hokkaido Univ. 6, 57-93.

Pedersen, P. M., 1980. Culture studies on complanate and cylindrical Scytosiphon (Fucophyceae, Scytosiphonales) from Greenland. - Br. phycol. J. 15, 391-398.

Provasoli, L., 1968. Media and prospects for cultivation of marine algae. In: Cultures and collections of algae. (Proc. U.S. - Japan Conference Hakone, 1966.) Ed. by A. Watanabe \& A. Hatton. Jap. Soc. Plant Physiol., Tokyo, 63-75.

Rhodes, R. G. \& Connell, M. U., 1973. The biology of brown algae on the Atlantic Coast of Virginia. II. Petalonia fascia and Scytosiphon lomentaria. - Chesapeake Sci. 14, 211-215.

Salisbury, F. B., 1981. Responses to photoperiod. In: Encyclopedia of plant physiology. N. S. Ed. by A. Pirson \& M. H. Zimmermann. Springer, Berlin, 12A, 135-167.

Tatewaki, M., 1966. Formation of a crustaceous sporophyte with unilocular sporangia in Scytosiphon lomentaria. - Phycologia 6, 62-66.

Wynne, M. J., 1969. Life history and systematic studies of some Pacific North American Phaeophyceae (Brown Algae). - Univ. Calif. Publs Bot. 50, 1-88. 